\title{
(息)
}

Citation:

Gibbon, J and Sylvester, C (2017) Thinking Like An Artist-Researcher About War. Millennium: Journal of international studies, 45 (2). pp. 249-257. ISSN 1477-9021 DOI: https://doi.org/10.1177/0305829816684261

Link to Leeds Beckett Repository record:

https://eprints.leedsbeckett.ac.uk/id/eprint/3824/

Document Version:

Article (Accepted Version)

Creative Commons: Attribution 4.0

The aim of the Leeds Beckett Repository is to provide open access to our research, as required by funder policies and permitted by publishers and copyright law.

The Leeds Beckett repository holds a wide range of publications, each of which has been checked for copyright and the relevant embargo period has been applied by the Research Services team.

We operate on a standard take-down policy. If you are the author or publisher of an output and you would like it removed from the repository, please contact us and we will investigate on a case-by-case basis.

Each thesis in the repository has been cleared where necessary by the author for third party copyright. If you would like a thesis to be removed from the repository or believe there is an issue with copyright, please contact us on openaccess@leedsbeckett.ac.uk and we will investigate on a case-by-case basis. 


\title{
Thinking Like An Artist-Researcher About War
}

\author{
Jill Gibbon and Christine Sylvester
}

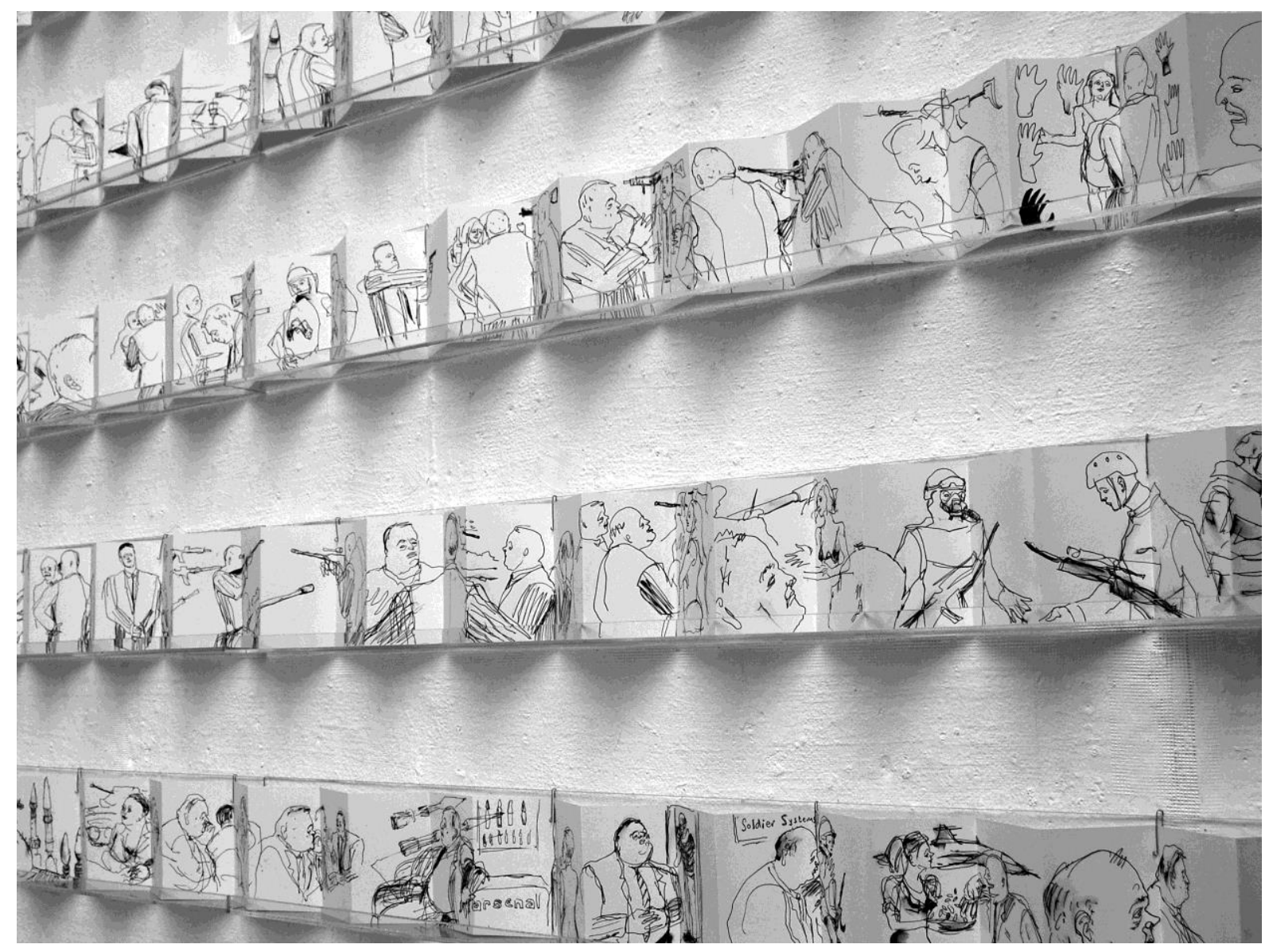

In Method Meets Art (2015), Patricia Leavy argues for thinking like both a researcher and an artist in order to create socially useful works. Christine Sylvester teams up with visual artist Jill Gibbon to think through her drawings about practices that can radicalize art/war consciousness and motivate action. Both authors bear in mind words George Grosz screamed nearly100 years ago: "What does it matter if you spend your time gold-plating the heels of boots or carving Madonnas. People are being shot..." The essay unfolds from a brief remembrance of debates about art and function and considers what it is to think like an artist-researcher (or not, as is often the case in IR war studies and art making) on issues of war. The co-authors present viewpoints on the drawing and end by working together toward a researcher-artist mode of being, doing and thinking about war through art.

Jill Gibbon, Artist and Senior Lecturer, Leeds Beckett University UK

Christine Sylvester, Professor, University of Connecticut USA, University of Gothenburg

A series of sketchbooks appear here. They have been drawn in arms fairs in London and Paris. The halls are crowded - a sea of men and occasional women in pinstriped suits. On show is a 
huge array of military equipment and security services. Teargas canisters are arranged in glass cabinets, missiles glint under spotlights, guns are lined up to try out against painted targets, tank barrels are raised. There are also body parts, not the casualties of war - they are nowhere to be seen - but displays of gloves, boots and gasmasks. Here, military equipment 'steps forth as a commodity, it is changed into something transcendent. ${ }^{1}$ A bomb becomes an object of exchange, a focus for fantasies and profit. Deals are facilitated with lavish hospitality. Hostesses weave through the traders, politicians and clients offering pretzels, wine, and lipstick smiles. A string quartet plays Mozart from the back of a military truck. Alliances are formed with a handshake, backslap, and glass of champagne.

The polite rituals hide a corrupt trade. Arms are sold to repressive regimes, authoritarian states, and countries engaged in aggressive wars. These deals are not illicit, but actively promoted by Western governments. The UK has sanctioned $£ 2.8$ billion worth of arms sales to Saudi Arabia since it started to bomb Yemen in March 2015, including bombs, air to air missiles, components for bombs, combat aircraft and military support vehicles. ${ }^{2}$ In the five years following the violent suppression of pro-democracy protests in Bahrain in 2011, the UK government facilitated $£ 45$ million of arms deals to the country including machine guns, grenades and assault rifles. ${ }^{3}$ During this period, Prince Andrew entertained the King of Bahrain at the Royal Windsor Horse Show, and the prime minister welcomed him to

\footnotetext{
${ }^{1}$ Karl Marx, Capital, Volume 1, 1867, http://web.stanford.edu/ davies/Symbsys100 Spring0708/Marx-Commodity-Fetishism.pdf.
}

2 'Stop Arming Saudi Arabia: Legal Action Launched!' CAAT News, 240, April/June 2016, 8-9. Saudi attacks have hit refugee camps, schools, hospitals, a wedding and aid facilities. Amnesty International claims it has evidence of a British made bomb used to destroy a civilian building (Amnesty International, Yemen Conflict: The UK Must Stop Selling Arms to Saudi Arabia, https://www.amnesty.org.uk/yemen-conflict-uk-must-stop-selling-arms-saudi-arabiaT, 2016). More than 5,800 people have been killed, tens of thousands injured, and 2.8 million displaced (O. Bowcott, "UK Fuelling Yemen Civil War With Arms Sales to Saudi Arabia says Amnesty", The Guardian, 17 December 2015: http://www.theguardian.com/world/2015/dec/17/uk-yemen-civil-war-armssales-saudi-arabia). Yet, when the EU parliament voted for an arms embargo on Saudi Arabia, David Cameron reassured the arms company BAE systems that he would continue to help it sell 'brilliant things' to the country (R. Mason, "David Cameron boasts of 'brilliant' UK arms exports to Saudi Arabia' The Guardian, http://www.theguardian.com/world/2016/feb/25/david-cameronbrilliant-uk-arms-exports-saudi-arabia-bae. 2016)

\footnotetext{
${ }^{3}$ Paul Gallagher, "British Arm Sales to Bahrain" The Independent a6872166.htmlhttp://www.independent.co.uk/news/uk/politics/bahrain-protesters-tortured-whilebritain-signs-45m-arms-deal-a6872166.html 2016 2
} 
Downing Street. ${ }^{4}$ The arms industry is given an appearance of civility through the hierarchical rituals of the establishment. Arms fairs are an extension of this. How to strip away the polite veneer?

The dada poet, Hugo Ball wrote, 'All satire and irony lead back to naivety.' 5 She started visiting arms fairs as an 'official war artist'. There was nothing official about her status - the title was self-appointed. That this was sufficient to bypass apparently stringent security checks indicates that the idea of the 'artist' has a cultural kudos that is particularly useful to institutions. The UK arms fair, DSEI, even offered to exhibit her work on the strength of the application. The offer was withdrawn as soon as they saw the drawings - indeed she was asked to leave. Following this, she gained access as a 'researcher' by submitting a sham abstract to a 'conference' that was taking place within the fair as part of a growing association between arms manufacturers and universities. The invitation was cancelled when she submitted the full paper. She now gets in as the managing director of a fictitious arms company by wearing a suit and paste pearls.

Art and university research, like a pinstriped suit, are often part of a veneer of civilization that normalizes war. As Walter Benjamin observed, 'There is no document of civilization which is not at the same time a document of barbarism. ${ }^{6}$ We begin by looking at the ways art and IR collude in the business of war. Then we use the drawings as a starting point to imagine a critical collaboration between art, activism and IR.

\section{What is the point of art?}

'What does it matter if you spend your time gold-plating the heels of boots or carving Madonnas.... People are being shot. There is mass profiteering. And hunger. People are being lied to. What is the point of art? ${ }^{7}$

\footnotetext{
${ }^{4}$ Paul Gallagher, and Daniele Palumbo, "Prince Andrew Under Fire for Hosting King of Bahrain", Independent, $\mathrm{http} / / \mathrm{www}$.independent.co.uk/news/uk/home-news/prince-andrew-under-fire-forhosting-king-of-bahrain-whose-regime-stands-accused-of-human-rights-9387725.html. 2014.

${ }^{5}$ Hugo Ball, Flight Out Of Time, A Dada Diary, Berkeley: University of California, 1996).

${ }^{6}$ Walter Benjamin, Illuminations, (London: Pimlico, 1999): 248.
} 
Art has an ambiguous role in capitalism. Separated from mainstream production by historical circumstances, it has an ethereal aura that at times provides a cloak for corruption. The dada artist George Grosz described this when he railed against 'the cloud-cuckoo-land tendencies of so-called sacred art... while military leaders painted in blood. ${ }^{8}$ Yet art also offers methods that are particularly suited to conveying the brutal excesses of capitalism. To understand this contradictory potential, it is necessary to look back at the historical disconnection of art from society.

The modern, western idea of art emerged in the C18th and C19th as a defensive reaction to the emphasis on reason in the enlightenment, and mass production in the industrial revolution. ${ }^{9}$ The word 'aesthetic' was coined in tandem, borrowed from the Greek to describe aspects of sensuous experience and expression overlooked by rational enquiry. ${ }^{10}$ As part of the division of labour in the C19th, art was defined as a realm of specialized aesthetic production. As a result art has come to represent a zone of sensuous experimentation and play, apparently unfettered by the demands of industrial and academic production. The freedom is relative - although art appears to be separate from capitalism, it is inevitably entangled within it. As Julian Stallabrass points out, high-end art offers a speculative market that mirrors the financial markets while giving capitalism a bohemian gloss. ${ }^{11}$ Even so, it is undeniable that the historical separation of art from industrial production has given artists an unusual degree of freedom, and this holds out the possibility that artistic practice might be put to radical use. The playwright Bertolt Brecht argued that art has the potential to reveal the inner workings of capitalism, 'discovering the causal complexes of society/unmasking the prevailing view of things of those in power. ${ }^{12} \mathrm{And}$, indeed, there is a reason that art might be

${ }^{7}$ George Grosz, 'George Grosz' in Dawn Ades, ed. The Dada Reader, A Critical Anthology (London: Tate Publishing, 2006): 310.

8 ibid

${ }^{9}$ Raymond Williams, Keywords (New York: Fontana Press, 1983): 40

${ }^{10}$ Terry Eagleton, The Ideology of the Aesthetic (London: Blackwell, 1990): 13.

${ }^{11}$ Julian Stallabrass, Art Incorporated, The Story of Contemporary Art ) Oxford: Oxford University Press, 2004): 5.

${ }^{12}$ Bertolt Brecht 'Brecht Against Lukacs' in T.Adorno, W.Benjamin , E.Bloch, B.Brecht, 4 
particularly well suited to this task - capitalism also uses aesthetic methods.

Art may have become known as the realm of the aesthetic, but aesthetic expression is not limited to art. Eagleton uses the term to describe the breadth of visceral experience and expression that lies outside the rational. 'The aesthetic concerns this most gross and palpable dimension of the human, which post-Cartesian philosophy, in some curious lapse of attention, has somehow managed to overlook. ${ }^{13}$ It is any form of experience that touches 'the gaze and the guts and all that arises from our most banal, biological insertion in the world. ${ }^{14}$ As such the aesthetic is dialectical, at once radical and reactionary. It describes both the ornaments of civilization, and the animal drives that subvert them. It conveys bonds of feeling that unite, and divide.

Many aspects of contemporary international relations seem to defy rational explanation wars against terror, 'defensive' arsenals that can destroy the planet, arms sales to repressive regimes. As Anne Orford argues 'in the seventeenth century and again today, reason cannot fully explain the violence unleashed by the state - or the international community - in the name of protection. ${ }^{15}$ President Eisenhower warned of the 'unwarranted influence' of the military-industrial complex and 'the potential for the disastrous rise of misplaced power'. ${ }^{16}$ How to study this? What does influence look, feel and smell like? As Eagleton puts it, 'How can reason, that most immaterial of faculties, grasp the grossly sensuous?' ${ }^{17}$ (1990: 15) Here, art can perhaps contribute.

But there is a catch. Art is particularly vulnerable to appropriation. Artworks may be able to

G.Lukacs, Aesthetics and Politics (London: Verso,1980): 82

${ }^{13}$ Eagleton, 1990: 13.

14 Ibid.

${ }^{15}$ Anne Orford, 'The Passions of Protection: Sovereign Authority and Humanitarian War' in Christine Sylvester, ed. Experiencing War (London: Routledge, 2011): 11.

${ }^{16}$ Dwight Eisenhower, The Farewell Address, 1961 https://www.eisenhower.archives.gov/research/online_documents/farewell_address.html.

${ }^{17}$ Eagleton, 1990: 15. 
convey the 'grossly sensuous' guises and effects of power, however such insights are drained of meaning if they are presented through the usual art world channels as valuable artifacts. Benjamin warned of photographs that 'make human misery an object of consumption. ${ }^{18}$ As Eagleton says, 'How idealist to imagine that art, all by itself, could resist incorporation!' 19 Benjamin argues that politically effective art is not just a matter of form or content. It is necessary also to change the means of production and dissemination. ${ }^{20}$ The task is to turn 'readers and spectators into collaborators. ${ }^{\text {,1 }}$ An alliance between IR, art, and activism might be a start.

\section{Art and IR}

For most of IR's history, readers and spectators have indeed been collaborators. They have collaborated in shaping a discipline that celebrates abstract theory, focuses more on the causes of wars than on the 'cannon fodder' fighting and caught in war's injurious content; and in US IR, hypothesis testing using large-N data sets is continually fashionable. Nordic countries have produced a sustained peace studies subfield and journals to match, from the Journal of Peace Research to Security Dialogue; however, the first one also showcases quantitative studies and both go along with the larger tendency in global IR to elevate abstract reasoning above the art and tears of war. The gritty politics of wars and peace are appropriated, absented, or drained of meaning in a good portion of the field's output. In addition, the Cold War ushered in strict border controls that delineated true IR from other fields. All the arts, where voices, dramas, stories and textures of conflict and dailiness have been readily available, were seen as far outside IR. They could be smuggled in only when studying regimes that consciously built aesthetics into their marketing efforts, e.g. Nazi gigantism in architecture and academic blandness in paintings, Soviet socialist realism, and the weapons parades once organized by both regimes and continued today by North Korea.

\footnotetext{
${ }^{18}$ Walter Benjamin, "The Author as Producer" in Charles Harrison and Paul Wood, Art in Theory 1900 - 1990 An Anthology of Changing Ideas (London: Blackwell, 1992), 487.

${ }^{19}$ Eagleton, 1990: 372.

${ }^{20}$ Benjamin, 1992: 486.

${ }^{21}$ Ibid, 488.

6
} 
There was so little openness in IR until fairly recently that one could apply the term censorship to describe refusals to countenance anything wandering in from outside established disciplinary borders. ${ }^{22}$ Censorship is, of course, a political act, one that artists are familiar with from the many occasions when artworks are declared offensive, blasphemous, heretical, dangerous, naked, and wrong in image and words. The Nazi Degenerate Art exhibits of 1939 showed modernist artworks stolen from German museums and Jewish collectors as the ugly, morally corrupt and despicable artifacts of social groups requiring elimination. Segue to the Cold War 1950s and US Congressional insistence on vetting American modernists before their works could be exhibited abroad, with the Museum of Modern Art (MOMA) in New York allegedly pushing back by promoting the abstract expressionist works painted by vetoed artists. Congress also tried to censor the National Endowment for the Arts in the late 1980s and 1990s, on the grounds that it was funding "controversial" art exhibitions that assaulted American symbols (e.g. the flag) as well as its heteronormative norms. And then there was the Enola Gay case that resulted in the cancellation of a planned exhibition at the Smithsonian for the $50^{\text {th }}$ anniversary of the end of World War II. It was to have shown one of the planes that had transported atom bombs to Japanese targets in 1945, but military leaders, Congressional members, and veterans balked at curator plans to indicate the extent of Japanese killed by those bombs. Some might also remember the fate of the International Freedom Center originally planned for the World Trade Center rebuild. Survivor censorship prevailed when a group called Take Back the Memorial began "warning New York that it was about to get a left-intellectual, blameAmerica museum of September 11...nearly overnight the Center's chief political backers [including Hillary Clinton] withdrew support and the project abruptly ended. ${ }^{23}$ In each case, critical aesthetics met silencing censors applying a politics of disapproval.

The sketchbooks have also survived a politics of disapproval centering both on the audacity of sketching within arms trade fairs and the images produced, which are not sympathetic to

\footnotetext{
${ }^{22}$ During the time of IR censorship, roughly before the mid-1990s, one journal reviewer mocked a manuscript I (Sylvester) had submitted, calling it a case of confusing art history "or some other field like that" for IR.

${ }^{23}$ Christine Sylvester, Art/Museums: International Relations Where We Least Expect It, (Boulder: Paradigm Publishers, 2009): 162.
} 
the event or the participants. That IR researchers are able to view these artist sketchbooks here exemplifies an artistic evasion of corporate-state censorship. As noted, it is not easy to get into such "fairs," or to be a masked interloper within the cultivated ambiance surrounding killer arms. The IR researcher can only imagine the anxiety that accompanies the renegade act of drawing instances of that "mass profiteering" Grosz condemns, amid the champagne, fruit, delicate chocolates, and missiles. And the quartet playing Mozart: an aesthetic flirtation with the old-school sense that where there is recognized art there is refinement. No violence here. No people being shot. Mozart off the back of a military truck in an arms fair? Code that dada. And code it international relations.

\section{A Short Collaborative Dialogue to Begin}

Sylvester: In Method Meets Art, Patricia Leavy argues for thinking both like a researcher and an artist in order to create socially useful work. ${ }^{24}$ Scope those sketches. The researcher-artist is at the far right end of the first full sequence visible in the image. She is ostensibly studying the catalogue of arms, the way academics might study the arms industry; only she is likely a potential buyer rather than a critical theorist. She looks comfortable, focused, at ease with the material she is reviewing. She could be someone I might know in IR. She could also be a spy, an outlaw in the arms fair, someone who is studying that catalogue with critical censorious purpose.

Gibbon: If we accept Eagleton's definition of the 'aesthetic' as aspects of human experience that lie outside reason, as 'that which is bound up with our creaturely life, ${ }^{25}$ then the term encompasses contradictory aspects of an arms fair. Beneath the polite façade are conflicting, disruptive drives and emotions. I am aware of this in myself. I may be wearing a suit, but I know I am a fake. The first day of an arms fair is the worst. I am gripped by fear - twisting guts, tense shoulders, creeping skin. Drawing while nauseous, I realize I am not alone; there is often a disjuncture between the respectable dress of my subjects and the uneasy figures within. John Berger describes drawing as 'an act of discovery' bringing to attention detail

\footnotetext{
${ }^{24}$ Patricia Leavy, Method Meets Art: Arts-Based Research Practice, $2^{\text {nd }}$ edition, (New York: The Guilford Press).

${ }^{25}$ Eagleton, 1990: 13.
} 
that might otherwise be overlooked. 'It is the actual act of drawing that forces the artist to look at the object in front of him. ${ }^{26}$ While drawing, I notice a sweaty lip, hunched shoulder, a contorted brow. Expressions of lust, anger and greed break through the façade. It is not just me who is acting a part.

Sylvester: Because of the contradictions these sketches reveal, we might consider the drawings as a set of research notes on arms fairs. Picasso would likely have gone along with that idea. He said: "I never made a painting as a work of art. It's all research." 27 Pictured in the sketches are many men, none fitting the image of the masculine warrior. The shoulders are indeed rounded. Fatigue is evident in those bodies, as are the too many glasses of bubbly consumed over the course of a day. Most of the men just stand around; not a single sale seems to be taking place. Is that the case? Are the fairs mostly about looking and hobnobbing, with actual sales deals taking place in some back lot? What does the arms sale look like, exactly? How is the money transferred? That the sketches picture arms fairs without evidence of arms deals raise questions about how to see, look into, conceptualize arms deals from arms fairs.

Even when they are smiling, the men do not look like happy fellows who have sealed any deal. And with the one exception of the woman perusing the we-know-not-what reading material in a concentrated and interested way, no other woman looks absorbed in anything having to do with actually selling and buying arms. They're arranging their bodies and draped attire, showing off legs in pointy shoes with heaven heels. They look everlastingly bored, like slumping stage props.

Gibbon: An arms fair is ostensibly an 'exhibition. ${ }^{28}$ No money changes hands, as if this would lower the tone. Deals take place later, after the hospitalities.

The business of arms trading is an example of what Jonathan Harris calls a 'dramatized

\footnotetext{
${ }^{26}$ John Berger, "Drawing is Discovery" The New Statesmen, (1953).

${ }^{27}$ Quoted in Leavy, 2015: 224.

${ }^{28}$ DSEI, Welcome to DSEI 2017, www.dsei.co.uk (2016)

9
} http://www.newstatesman.com/culture/art-and-design/2013/05/john-berger-drawing-discovery; 
public life performance, ${ }^{29}$ the acting out of public, professional roles. Harris describes a 'miserable gap' between the expectations of how these performances should look, and the way that individual bodies perform, usurped by conflicting emotions and drives. ${ }^{30}$ Drawing is never objective - there is always a choice of what to include, and what to leave out. I focus on the 'miserable gap' in arms traders' performances that disrupt the civility of the show - a lecherous leer, an overly enthusiastic turn with a gun, the continual desperate drinking. Only one group maintains the mask of respectability - the mannequins that are scattered across the hall displaying private security kit. The plastic flesh is unblemished by rich food, the classical features show no emotion. They contrast cruelly with the traders who surround them. Drawing offers a method to convey the contradictory aesthetics of an arms fair - the formality of the exhibition, and the stirrings of "creaturely life' ${ }^{31}$ that disrupt it.

Sylvester: The weapons that are set about also look bored. Inert, but potentially not inert at all, they are ponderous poke-ups here and there, something for the men to lean against and the women to play to. The anthropologist Veena Das is convinced that social researchers should descend into the ordinary more than we do, where much of life is experienced and recovered while researchers are looking higher up for significance. ${ }^{32} \mathrm{~A}$ sense haunts these sketches that desultory arms fairs are part of the ordinariness that creeps over war. War veterans describe it as a lot of standing around, a lot of waiting: "My days passed sitting in the dust, throwing rocks into a bucket, missing, didn't matter." 33 Of course, there are hellbreaking moments of war, too. But let's not go there. This is a refined arms fair, after all. The

${ }^{29}$ Jonathan Harris, Dead History, Live Art? Spectacle, Subjectivity and Subversion in Visual Culture Since the 1960s (Liverpool University Press and Tate Liverpool, 2007): 14.

${ }^{30}$ Ibid.

${ }^{31}$ Eagleton, 1990: 13.

${ }^{32}$ Veena Das, Life and Words: Violence and the Descent into the Ordinary (University of California, 2007).

${ }^{33}$ Kevin Powers, The Yellow Birds: A Novel (New York: Little, Brown, 2012): 155. 
sketches communicate the interregnums of war, moments when security sentries face nothing more threatening than an artist, a researcher with sketchbooks.

Gibbon: These concertina sketchbooks appeared in Shock and Awe, a group exhibition of war art at the Royal West Academy (RWA) in Bristol UK, 2014. There was space in that gallery to show the complete sketchbooks with mis-drawn lines, smudges and interruptions. That conveys something of the experience of being inside a fair, and perhaps makes it possible to imagine trespassing its boundaries. The RWA is unusual in encouraging political dialogue through the text that accompanied the drawings and through artist's talks during the exhibition. Still, in my world of art, the emphasis on individual artists means that political concerns can all too easily be interpreted as an individual quirk.

Sylvester: Early feminist IR concerns were similarly deemed 'quirks' of some women scholars. An artist-researcher traveling incognito can evade the censors and pursue an ethics of care, ethics of protest, or right to information, unfettered. The brilliance of the Guerrilla Girls feminist group lies partly in the costuming: gorilla masks hide identities and enable clever picture messages about women's mistreatment by arts institutions to be heard, seen, and appreciated. Assuming a false identity, though, is something university ethics boards might not tip as a legitimate research tool if proposed by social science researcher-artists. If the researcher is an artist, romantic ideas of artistic 'genius' pegged to academic border politics (art is not a social science) lets her off the hook. The fake pearls do too if the venue is an arms fair security. Such are the vagaries of the large censorship industry.

Gibbon: Sara Bevan, curator at the Imperial War Museum, suggests that contemporary forms of violence demand new approaches to the curation of war art. ${ }^{34}$ Janna Graham, at the Nottingham Contemporary Gallery argues that if creativity is to be harnessed as a critical tool, there must be non-hierarchical collaborations between artists, curators, educators and activists. ${ }^{35}$ Sylvester's Experiencing War was an example of this kind of collaboration, where

\footnotetext{
${ }^{34}$ Sarah Bevan Art From Contemporary Conflict, (London: Imperial War Museum, 2015).

${ }^{35}$ Janna Graham, "Spanners in the Spectacle: Radical Research at the Frontlines", Fuse Magazine, 11
} 
people from a range of backgrounds presented diverse experiences of war. ${ }^{36}$ In the future, such events could be held in galleries, museums, and contested public spaces.

Sylvester: Indeed, and invite the woman in the sketchbook who is reading in an arms fair. No matter her motives, at that moment she is defying all efforts to get her into the weapons game and out of a book.

Gibbon: Yes, but here comes that security guard.

'It's you, again. You and your drawings have been linked to protest. Get out'.

It is the guard's task to keep art, research and protest separated.

The challenge is to bring them together.

April 1, 2010.

${ }^{36}$ Christine Sylvester, ed. Experiencing War, (London: Routledge, 2011). 